\title{
Trends in Age Structure and Ageing Population in Nepal
}

Kamala Bhandari (M. Phil.)*

\begin{abstract}
The study attempts to examine the trend in the age structure of population and elderly population and its geographic and demographic variation in respect to the fedral structured country based on the census data. The study found noticeable changes in the age structure of the population in the country. The share of children is shrinking with growing proportions of older population aged 60 and above throughout the Nation. More than half of population falls in the 15-59 years category that conforms Nepal population is primarily young, which is also known as the 'youth bulge' or 'demographic dividends' and will shift into the category of 60 and above in a few decades. Hence the Nepal's population is gradually ageing over the years. The proportion of children and old aged population was observed higher in Mountain (38\% and 8.8\%)), rural area (38\% and $8.8 \%$ ) and working age population was in hill region (58\%) and in urban area (59\%) along with province 3. According to the 2011 population census, the proportion of population aged 60 and above is 8.1 percent, majority of them are in their sixties (69\%) and observed same in all regions of the country. As measured by sex ratio in both rural and urban area female outnumber male and also reported the expectation of life is higher for female then male in this age group of the country. Among the 77 districts Gorkha (12.75\%) reported the highest, and Jajarkot (5.12\%), reported the lowest proportion of their population being old.
\end{abstract}

Key words: Age structure, distribution, elderly population \& demographic dividend.

\section{Introduction}

Age structure of the population represents distribution of population by age or age group. For the purpose of easy understanding and easy comparison it can be divided into three category known as child aged population (0-14 years), working age population (15-59 years) and old aged population 60 and above. Ageing is understood in two ways: individual ageing as the process of individuals growing older, or maturing 'progressive changes related

*Ms. Bhandari is a Faculty Associate at the Department of Population Studies, Patan Multiple Campus, TU, Lalitpur, Nepal.Email:pkamala2073@gmail.com 
to the passage of time. It is the multidimensional process of physical, psychological and social change. Some diminutions of ageing grow and expanded over time which others decline reaction time, and population or demographic ageing as the process whereby older individuals become a proportionately larger share of the total population (Joshi, 2013).

First World Assembly on Ageing (1982), Vienna and Second World Assembly on Ageing (2002), Madrid has defined that 60 years old and above aged population is called old age population. Similarly in United Nations Conference on Ageing and Urbanization in 1991 the term elderly is defined as the population aged 60 years and above. For international comparison, the population aged 65 years and above is categorized under the ageing population. Many of the more developed countries classify a person as aged only when he/ she reach the age of 65 years (Bisht, 2006). The Government of Nepal classifies the age 60 years population as aged for the case of comparison. In Nepal Senior Citizen Act 2063 and Social security Programme Implementation Action Method 2065 clearly defined that person aged 60 years and above are placed under elderly or old persons.

Population ageing is defined as gradual increase in the proportion of the elderly population aged 60 years or older in the total population while the proportion of children and adolescent decrease. It is a natural outcome of demographic transition from high fertility and mortality to low fertility and mortality. An increase in the longevity of the individuals or an increase in the average length of life pertaining to a population result from improvement in the quality of the environment and from the medical advances among other factors (Shryock, 1976).

Worldwide population ageing has been considered one of the most important demographic phenomena that the older people are increasing almost the entire world. It is the dynamic process of demographic and socio economic transformation which reflects the increasing in the share of the elderly population aged 60 and over on the total population. According to the results of the 2017 Revision of UN, the world's population reached nearly 7.6 billion in mid-2017. The world has added one billion people since 2005 and two billion since 1993. In 2017, an estimated 50.4 percent of the world's population was male and 49.6 percent female. In 2017, 9 percent of the global population was under age 5, 26 percent was under age 15, 13 percent was aged 60 or over and 2 percent was aged 80 or over. During 2010 to 2015 the average annual growth rate of global population aged 60 or over was almost three times $(3.3 \%)$ that recorded for the total population $(1.1 \%)$ that climbed from 2.0 percent per year during 2000 to 2005 (UN, 2015). Hence, population ageing is a phenomenon that we can no longer ignore (UN, 2017).

Nepal is in the phase of age structure transition with a large proportion of young working age 
population. This phase is also commonly known as the phase of youth bulge; demographic dividends or the window of opportunity. This present phase and the consistent increment in the share of older age population over the year signify that the elderly population will continue to increase in the years to come. Data shows more than half of the population (56.9\%) falls in the 15-59 years category which conforms that the Nepali population is primarily young. The large proportion of youth also indicates that the population is gradually ageing over the years. In a few decades the youth will shift into the category of 60 and above, thereby increasing the proportion of the aged population. Thus the decreasing population of children and the increasing proportion of the working age and the older population affirm that Nepal is undergoing age structure transition and the population is gradually ageing (Limbu, 2012). This change in the age structure of the population may be due to the Nepal's demographic situation that is characterized by declining mortality and a steady decline in fertility along with increasing life expectancy at birth. This study is devoted to highlight changing in the age structure of the population and assess the geographic and demographic variation of elderly population in Nepal. The term "elderly population" and "old aged population" are used interchangeably throughout this paper.

\section{Objectives}

The main objective of the study is to examine the trends of age structure and ageing population in Nepal. The specific objectives of the study are to assess the age distribution of the population by geographic regions and to assess the distribution of elderly population and its demographic variation in respect to the new structured sub regions of the country.

\section{Significance}

The finding of this study plays a significant role to provide additional ideas and input about the changing pattern of age structure and the geographic and demographic variation of aged population for individual, researcher and students, social, legal and political activists or advocates. The study will provide reference material for those who are interested about it. Furthermore, the finding of this study will be helpful to policy maker, planner of the Government of Nepal to evaluate, revise and implement the elderly related policies.

\section{Methodology}

The paper follows the descriptive and exploratory research method based on the existing data sheet of 2011, National Population Census and other previous censuses data collected by CBS. The data from these sources are used to examine the trend in the age structure of population and elderly population and its geographic and demographic variation in 
respect to the new fedrel structured sub regions of the country. Furthermore, this paper is based on review of existing literature mainly books, journal, article and reports.

\section{Interpretation and Analysis of the Data}

\section{Size and Growth of the Nepalese Population}

The population enumerated in 1961 was 9.4 million increased to 23.1 million in 2001 with its annual growth rate of more than 2 percent for 40 years. At the time of the latest census 2011, the population of Nepal stood at 26.4. million, has increased 14.4 percent during the past decade with an average annual growth rate of 1.35 percent far lower than the 2.25 percent recorded in the 2001 census, may be due to the high volume of the absentee population.

Table-1: Population size, growth rate and broad age distribution of Nepal, 1952/54 -2011

\begin{tabular}{|l|c|c|c|c|c|c|c|c|}
\hline $\begin{array}{l}\text { Census } \\
\text { Years }\end{array}$ & $\begin{array}{c}\text { Proportion } \\
\text { Population } \\
\text { below 15 }\end{array}$ & $\begin{array}{c}\text { Growth } \\
\text { Rate } \\
\text { (percent) }\end{array}$ & $\begin{array}{c}\text { Population } \\
15-59 \\
\text { (percent) }\end{array}$ & $\begin{array}{c}\text { Growth } \\
\text { Rate } \\
\text { (percent }\end{array}$ & $\begin{array}{c}\text { Population } \\
60 \text { and above } \\
\text { (percent) }\end{array}$ & $\begin{array}{c}\text { Growth } \\
\text { Rate } \\
\text { (percent) }\end{array}$ & $\begin{array}{c}\text { Total } \\
\text { Population }\end{array}$ & $\begin{array}{c}\text { Growth } \\
\text { Rate } \\
\text { (percent) }\end{array}$ \\
\hline $1952 / 54$ & 38.4 & & 56.6 & & 5.0 & & $8,256,625$ & 2.30 \\
\hline 1961 & 39.9 & & 54.4 & & 5.3 & & $9,412,996$ & 1.65 \\
\hline 1971 & 40.5 & 2.2 & 53.9 & 1.9 & 5.6 & 2.6 & $11,555,983$ & 2.07 \\
\hline 1981 & 41.4 & 2.9 & 52.9 & 2.5 & 5.7 & 2.8 & $15,022,839$ & 2.62 \\
\hline 1991 & 42.4 & 2.3 & 51.8 & 1.9 & 5.8 & 2.2 & $18,491,097$ & 2.10 \\
\hline 2001 & 39.4 & 1.3 & 54.1 & 2.5 & 6.5 & 3.2 & $23,151,423$ & 2.24 \\
\hline 2011 & 34.9 & 0.3 & 57.0 & 2.1 & 8.1 & 3.8 & $26,494,504$ & 1.35 \\
\hline
\end{tabular}

Source: CBS, 2014

Table 1 shows the percentage distribution of population by three broad age categories with its average annual growth rates for the various censuses. Table illustrates, among these age groups, more than half of the population falls in the 15-59 years categories, which conforms that the Nepali population is primarily young and Nepal is experiencing the window of opportunity. Table also shows the trend of decreasing in the proportion and growth rate of population below 0-14 years since the last decade and increasing in the proportion and growth rate of working and old aged population. It may be due to the declining fertility and overall improvement in the mortality. This structure affirms that Nepal is undergoing age transition and the population is gradually ageing.

\section{Age Distribution of Population by Ecological Region}

Nepal has three distinct ecological regions. These are Mountains, Hills and Tarai. Table 
2 presents the data on percentage distribution of population by three broad age categories and their intercensal growth rates of these regions for the census 1981 to 2011.

Table-2: Age distribution of population and its annual growth rate by ecological region, $1981-2011$

\begin{tabular}{|c|c|c|c|c|c|c|}
\hline $\begin{array}{l}\text { Ecological } \\
\text { Belt }\end{array}$ & $\begin{array}{l}\text { Census } \\
\text { Years }\end{array}$ & $\begin{array}{l}\text { Population } \\
\text { aged } 0-14 \\
\text { (percent) }\end{array}$ & $\begin{array}{l}\text { Population } \\
\text { aged 15-59 } \\
\text { (percent) }\end{array}$ & $\begin{array}{c}\text { Population } \\
60 \text { and above } \\
\text { (percent) }\end{array}$ & \multicolumn{2}{|c|}{$\begin{array}{l}\text { Population Growth Rate } \\
\text { (percent) }\end{array}$} \\
\hline & & & & & $\begin{array}{c}\text { Growth Rate } \\
\text { (r) }\end{array}$ & Pop $60^{+}$ \\
\hline \multicolumn{7}{|l|}{ Mountain } \\
\hline & 1981 & 38.86 & 54.93 & 6.21 & 1.35 & - \\
\hline & 1991 & 41.40 & 52.40 & 5.81 & 1.02 & 1.0 \\
\hline & 2001 & 40.84 & 52.68 & 7.16 & 1.57 & 1.8 \\
\hline & 2011 & 38.22 & 52.97 & 8.80 & 0.54 & 3.8 \\
\hline \multicolumn{7}{|l|}{ Hill } \\
\hline & 1981 & 40.79 & 53.15 & 6.06 & 1.65 & - \\
\hline & 1991 & 42.40 & 51.35 & 6.20 & 1.61 & 1.9 \\
\hline & 2001 & 38.92 & 54.18 & 7.00 & 1.97 & 2.9 \\
\hline & 2011 & 33.46 & 57.93 & 8.61 & 1.06 & 3.3 \\
\hline \multicolumn{7}{|l|}{ Terai } \\
\hline & 1981 & 42.47 & 52.32 & 5.21 & 4.11 & - \\
\hline & 1991 & 42.57 & 52.12 & 6.25 & 2.75 & 2.9 \\
\hline & 2001 & 39.46 & 54.31 & 7.92 & 2.62 & 3.7 \\
\hline & 2011 & 35.70 & 56.57 & 7.63 & 1.72 & 4.3 \\
\hline
\end{tabular}

Source: National Population Census, Datasheet 1991, 2001, 2011 \& CBS 2014

Data of the table 2 clearly shows since 1991 the proportion of child population under age 15 was decreasing with increasing in the working age population aged 15-59 and the elderly population aged 60 and above in all regions over the years. Of these three regions mountain region shares the higher proportion child population $(38.22 \%)$ and elderly population $(8.80 \%)$ whereas hill region shares higher proportion of working age population $(57.93 \%)$.

Table 2 also reveals the average annual growth rate old age population is always greater then population growth rate and shows it was in increasing trend in all eco belts of the country over the years. Among them the speed of elderly population growth rate was 
observed highest in Tarai (4.3\%), which is almost 4 times higher than total population growth rate and in Mountain, it was reported 3.8 percent as compared with 0.54 percent of total population growth rate. Hill accounted 3.3 percent in 2011, which is also 3 times higher than total population growth rate. All of these indicators show elderly population is growing faster in the country.

\section{Age Distribution of Population by Provincial and Rural Urban Residence}

The analysis of this section, is devoted to the new structure of the country i.e. 293 municipalities known as urban area and 460 rural municipalities (rural area) as well as seven states of the country. Due to this reason table also shows the data on the percentage distribution of population of these areas.

Table-3: Age distribution of population by provincial and rural urban residence, 2011

\begin{tabular}{|c|c|c|c|c|c|c|}
\hline \multirow[b]{2}{*}{ Areas } & \multirow{2}{*}{$\begin{array}{c}\text { Population } \\
\text { aged 0-14 } \\
\text { (percent) }\end{array}$} & \multirow{2}{*}{$\begin{array}{l}\text { Population } \\
\text { aged 15-59 } \\
\text { (percent) }\end{array}$} & \multirow{2}{*}{$\begin{array}{c}\text { Population } \\
60 \text { and above } \\
\text { (percent) }\end{array}$} & \multirow{2}{*}{$\begin{array}{l}\text { Percentage } \\
\text { of population } \\
\text { of the total } \\
\text { population }\end{array}$} & \multicolumn{2}{|c|}{ Growth Rate (percent) } \\
\hline & & & & & $\begin{array}{c}\text { Total } \\
\text { Population }\end{array}$ & $\begin{array}{c}\text { Population } \\
60 \text { and } \\
\text { above }\end{array}$ \\
\hline Urban & 33.3 & 58.96 & 7.8 & 63.2 & - & - \\
\hline Rural & 37.7 & 53.5 & 8.8 & 36.8 & - & - \\
\hline Provience-1 & 32.9 & 58.5 & 8.8 & 17.2 & 0.76 & 3.6 \\
\hline Provience-2 & 38.6 & 53.9 & 8.5 & 20.4 & 1.60 & 3.7 \\
\hline Provience-3 & 28.9 & 62.9 & 9.3 & 20.9 & 1.91 & 3.9 \\
\hline Provience-4 & 32.5 & 56.9 & 7.8 & 9.1 & 0.37 & 2.7 \\
\hline Provience-5 & 36.3 & 55.8 & 7.9 & 16.98 & 1.29 & 3.5 \\
\hline Provience-6 & 41.6 & 52.3 & 3.3 & 5.9 & 1.80 & 7.8 \\
\hline Provience-7 & 39.5 & 52.9 & 5.5 & 9.6 & 1.53 & 4.3 \\
\hline Nepal & 39.1 & 56.96 & 8.1 & 100 & 1.35 & 3.8 \\
\hline
\end{tabular}

Source: Data Sheet 2011, National Population Census

Above data shows the proportion of population living in urban area is higher $(63.2 \%)$ than in rural area (36.8\%), which is reverse than previous census, probably due to the reasons that many more rural areas are recently declared as the municipalities have been added in urban population and the inflow of rural population to urban centers. 
Among the seven proviences, provience number 3 is the largest which constitute 20.9 percent of the total population with the higher average annual growth rate of population of 1.9 percent followed by state two (20.4\%) with average annual growth rate of 1.60 percent, and the smallest is province six of 5.9 percent population with average annual growth rate of 1.3 percent followed by state four (9\%). During 2001 to 2011 decade 27 districts of the country had negative population growth rate and in provience four, 80 percent of districts experienced negative population growth rate.

Data of the table 3 shows the wide variation in the proportion of these three broad age group of the population and the growth rate of old aged population by rural urban residence and seven states of the country. Large share of child and elderly population was observed in rural area and working aged population in urban area, which may be due to the migration of young people from rural to urban area. Of the seven proviences it is noted that the highest proportion of population of working age $(62.9 \%)$ and old age $(9.3 \%)$ was observed in province three followed by province one $(58.5 \%$ and $8.8 \%$ respectively) which are higher than the national level and lowest in province 6 with the high proportion of population of $0-14$ years $(41.6 \%)$.

Table 3 also presents that all provinces average annual growth rate of elderly population are greater than the total population growth rate. Highest elderly population growth rate is observed in province 6 that is almost 7 times higher than the total population growth rate followed by province seven $(4.3 \%)$ and $3(3.9 \%)$, and lowest but higher then total population growth rate was observed in province $4(2.7 \%)$. It indicates the age structure of the population is in favor of elderly population aged 60 and above in Nepal.

\section{Distribution of Elderly Population by Sex}

This section tries to analyze the situation in the proportion of elderly population by sex and life expectancy for 60 and above populations for different sub regions of the country. Sex ratio is used to explain the sex variation instead of percentage. 
Journal of Population and Development, June 2020 | Kamala Bhandari /Trend in Age Structure and Ageing ...

Table-4: Proportion of the elderly population and life expectancy by sex in Nepal, 2011

\begin{tabular}{|c|c|c|c|c|}
\hline \multirow{2}{*}{ Areas } & \multirow{2}{*}{$\begin{array}{l}\text { Proportion of population } \\
\text { aged } 60 \text { and above }\end{array}$} & \multirow{2}{*}{$\begin{array}{l}\text { Sex ratio of population } \\
\text { aged } 60 \text { and above }\end{array}$} & \multicolumn{2}{|c|}{ Life expectancy at aged 60 and above } \\
\hline & & & Male & Female \\
\hline Mountain & 8.8 & 93 & 15.6 & 17.3 \\
\hline Hill & 8.6 & 92 & 16.5 & 18.1 \\
\hline Terai & 7.6 & 104 & 15.8 & 17.4 \\
\hline Urban & 7.8 & 97 & 17.2 & 18.8 \\
\hline Rural & 8.8 & 99 & 15.4 & 16.1 \\
\hline Provience-1 & 8.8 & 100 & 16.4 & 18.0 \\
\hline Provience-2 & 8.5 & 109 & 16.0 & 17.7 \\
\hline Provience-3 & 9.3 & 93 & 16.4 & 18.0 \\
\hline Provience-4 & 7.8 & 91 & 16.4 & 18.0 \\
\hline Provience-5 & 7.9 & 102 & 16.3 & 17.9 \\
\hline Provience-6 & 3.3 & 98 & 15.2 & 16.8 \\
\hline Provience-7 & 5.5 & 85 & 15.8 & 17.6 \\
\hline Nepal & 8.1 & 98 & 16.1 & 17.6 \\
\hline
\end{tabular}

Source: Data Sheet 2011, National Population Census

Of the total elderly population, the proportion was observed higher in Mountain $(8.80 \%)$ then in other regions followed by Hills. As in case of sex ratio data reflects elderly females outnumber the males in these two regions except Terai (104) i.e. male outnumber the female in 2011. Data also reveals elderly female live longer than male or the probability of surviving for women is higher than male in all regions of the country.

Similarly, the percentage of the elderly population observed higher in rural $(8.8 \%)$ then in urban area $(7.8 \%)$. As measured by sex ratio in both rural and urban area female outnumber male and also reported the expectation of life is higher for female then male in this age group of the country. As well as The proportion of the elderly population is high in province 3 with high life expectancy for the population $60+$ and low in province 6 with low life expectancy. It ranges from 3.31 percent in province 6 to 9.26 percent in province 3 (low to high). In case of sex ratio data clearly shows except province 1, 2, and 5 , in remaining other area, of the total elderly population female outnumber the male that indicates a lower mortality in the female population and the expectation of life of female is higher than male in all state of Nepal. 


\section{Distribution of Elderly Population by Age Groups in Nepal}

For easily understood and to make comparable elderly people can be divided into three broad age groups and defined as

- The Young Old, which includes those between 60 and 69 years of age

- The Old Old, which includes those between 70 and 79 years of age

- The Oldest Old, which comprises those above 80 years of age and above.

The percentage distribution of old aged population by three broad age groups at national level with three ecological belts and rural urban residence and provinces for the 2011 population census is presented in table 5 .

Table-5: Distribution of elderly population by age groups in Nepal, 2011

\begin{tabular}{|c|c|c|c|c|c|c|c|}
\hline \multirow[b]{2}{*}{ Areas } & \multicolumn{2}{|c|}{ Aged 60-69 } & \multicolumn{2}{|c|}{ Aged 70-79 } & \multicolumn{2}{|c|}{ Aged 80 and above } & \multirow{2}{*}{$\begin{array}{c}\text { Total } \\
\text { Percent }\end{array}$} \\
\hline & Percent & Sex ratio & Percent & Sex ratio & Percent & $\begin{array}{l}\text { Sex } \\
\text { ratio }\end{array}$ & \\
\hline Mountain & 5.3 & 92 & 2.6 & 94 & 0.9 & 93 & 8.8 \\
\hline Hill & 5.0 & 92 & 2.6 & 95 & 0.98 & 88 & 8.6 \\
\hline Terai & 4.9 & 103 & 2.1 & 109 & 0.7 & 96 & 7.6 \\
\hline Urban & 4.7 & 97 & 2.3 & 100 & 0.8 & 88 & 7.8 \\
\hline Rural & 5.3 & 97 & 2.6 & 104 & 0.9 & 97 & 8.8 \\
\hline Provience-1 & 5.2 & 100 & 2.6 & 103 & 0.95 & 92 & 8.8 \\
\hline Provience- 2 & 5.9 & 107 & 2.1 & 114 & 0.5 & 101 & 8.5 \\
\hline Provience-3 & 5.7 & 96 & 2.6 & 92 & 1.0 & 85 & 9.3 \\
\hline Provience-4 & 3.2 & 88 & 3.3 & 97 & 1.3 & 90 & 7.8 \\
\hline Provience-5 & 4.9 & 99 & 2.3 & 109 & 0.7 & 101 & 7.9 \\
\hline Provience- 6 & 1.5 & 95 & 1.4 & 109 & 0.4 & 100 & 3.3 \\
\hline Provience-7 & 2.7 & 83 & 2.2 & 87 & 0.6 & 85 & 5.5 \\
\hline Nepal & 60.9 & 96 & 29.3 & 100 & 9.9 & 92 & 100 \\
\hline
\end{tabular}

Source: Data Sheet 2011, National Population Census

Data clearly indicates that with increasing in age decreasing in the size of population. Of the total older population majority of them are in their sixties, in all regions of the country and overall it accounts 60.9 percent. Similarly, the population aged 70-79 constitute 29.3 
percent and remaining 80 and over holds 9.9 percent of the total older population in Nepal. This is expected in view of the recent history of ageing in Nepal.

Among these three broad age groups of elderly population, except for age group 70-79, in the rest two other groups female out number male, indicating continuation of excess female over male mortality almost throughout the life span. Similarly, for the age group $60-69$ except for terai regions, the state 2 and 1, the rest other regions had low sex ratio i.e. female outnumber the male.

\section{Districts Having Highest and Lowest Proportion of Elderly Population}

In the new structured of the country, Nepal is divided into 77 districts. Among the 77 districts, data are presented $10 / 10$ districts having the highest and lowest percentage of aged population in the country as follows.

Table-6: Distribution of elderly population having the highest and lowest percentage in Nepal, 2011

\begin{tabular}{|l|c|l|c|}
\hline \multicolumn{2}{|c|}{$\begin{array}{c}\text { Districts having the highest percent of elderly } \\
\text { population } 60 \text { years and above }\end{array}$} & \multicolumn{2}{c|}{$\begin{array}{c}\text { Districts having the lowest percent of elderly } \\
\text { population } 60 \text { years and above }\end{array}$} \\
\hline \multicolumn{1}{|c|}{ Districts } & $\begin{array}{c}\text { Percentage of population } \\
60\end{array}$ & \multicolumn{1}{c|}{$\begin{array}{c}\text { Districts } \\
\text { Percentage of population } \\
60+\end{array}$} \\
\hline Gorkha & 12.8 & Jajarkot & 5.1 \\
\hline Lamjung & 12.6 & Jumla & 5.5 \\
\hline Syangja & 12.2 & Rukum & 5.7 \\
\hline Mustang & 11.8 & Dolpa & 5.8 \\
\hline Ramechhap & 11.6 & Kathmandu & 6.0 \\
\hline Dolakha & 11.6 & Kalikot & 6.2 \\
\hline Parbat & 11.6 & Salyan & 6.2 \\
\hline Myagdi & 11.4 & Surkhet & 6.4 \\
\hline Sindhupalchowk & 11.2 & Parsa & 6.6 \\
\hline Gulmi & 11.1 & Dailekh & 6.6 \\
\hline
\end{tabular}

Source: Data Sheet 2011, National Population Census

Table 6 shows the highest proportion of elderly population for ten districts with life expectancy at birth. Districts including Gorkha (12.75), Lamjung (12.64\%) and syangja $(12.24 \%)$ reported the highest proportion of elderly population and remaining other seven districts have almost same percentage of elderly population, whereas Parbat had the highest life expectancy followed by Gulmi and Syangja. 


\section{Conclusion}

The study is about to assess the trend in the age structure of population and elderly population with its variation in respect to the new federal structured sub regions of the country based on raw data sheet of 2011 national population census and other population census data published by Central Bureau of Statistics Nepal. The result of the study shows noticeable changes in the age structure of the population in the country, such that the share of children is shrinking and older persons continues to grow. The proportion and the average annual growth rate of population below 15 years was decreasing over the years since 1991 to 2011 with increasing in the proportion and growth rate of population aged 15 to 59 years and aged 60 and above. Of the total population, more than half of the population falls in the $15-59$ years categories $(57 \%)$ that suggest Nepal is experiencing the window of opportunity known as 'population dividend'. The growth rate for elderly population is always more than the total population growth rate in Nepal. This structure affirms that Nepal is undergoing age transition and the population is gradually ageing coming years.

The large percent of senior people $(8.80 \%)$ of old age groups and child aged groups $(38.22 \%)$ are living in mountain belt and working age population $(58 \%)$ live in hill region and higher proportion of population of working age and old age was observed in province 3 and higher percentage of population below 0-14 years was observed in province six. The proportion of population aged 60 and above is 8.1 percent, increased from 5.2 percent in 1961. This indicates the aged population is rising steadily in Nepal. Of the total elderly population in 2011, majority of them are in their age group 60-69 (60.86\%), followed by $70-79(29.26 \%)$ and 80 and above $(9.88 \%)$. This scenario of age variation was observed in all sub regions of the country. This is expected in view of the recent history of ageing in Nepal. Data on sex ratio of older population reveals female outnumbered the male almost all regions except terai and all ages except 70-79 of the country and Life expectancy at age 60 also reveal female live longer than male.

Among the 77 districts Gorkha (12.75\%), Lamjung (12.64\%) and Syangja (12.24\%) reported the highest proportion of elderly population and Jajarkot (5.12\%), Jumla (5.53\%), Rukum (5.67\%), and Dolpa (5.78\%) reported the lowest proportion of their population being old. Hence, from the above explanation the study, the age structure of the country is expected to change significantly over the next decades. Age structure of the population is in favor of elderly persons aged 60 and above, it indicates the starting of ageing dynamics in Nepal, which will have adverse effect on social structure and economy in the long run. 


\section{References}

Bisht, P. S. (2006). The condition of the elderly people in Kathmandu city. An Unpublished Dissertation Submitted to the Faculty of Humanities and Social Science, Tribhuvan University in Fulfilment of Requirement for the Degree of Doctor of Philosophy in Population Studies. Kritipur: Central Department of Population Studies T.U, Nepal.

Central Bureau of Statistics (CBS). (1981). Population monograph of Nepal. Volume I. Kathmandu: National planning Commission Secretariat, Central Bureau of Statistics, and Nepal.

Central Bureau of Statistics (CBS). (1991). Population monograph of Nepal. Volume I. Kathmandu: National Planning Commission Secretariat, Central Bureau of Statistics, Nepal.

Central Bureau of Statistics (CBS). (2003). Population monograph of Nepal. Volume I. Kathmandu: National Planning Commission Secretariat, Central Bureau of Statistics, Nepal.

Central Bureau of Statistics (CBS). (2014). Population monograph of Nepal. Volume I. Kathmandu: National Planning Commission Secretariat, Central Bureau of Statistics, Nepal.

Joshi, M. R. (2013). Social and health care status of elderly: A case study of Dhading municipality in Kailali. An Unpublished Dissertation Submitted to CDPS, T.U in Partial Fulfilment of the Requirement for the Degree of Master Philosophy in Population Studies. Kirtipur, Nepal.

Limbu, A. (2012). Age structure transition and senior citizens in Nepal: The impending challenges. Alliance for Social Dialogue, Policy Research Fellowship, Program 2012.

Shryok, H. S., Siegel, J. S., \& Associates (1976). The methods and materials of demography. New York: Academic Press, Inc. United States.

United Nation (UN). (2017). World population prospectus, revision, 2017. New York: Department of Economomic and Social Affairs Population Devision, United States. 